\title{
Spatial scaling of recruitment in four continental shelf fishes
}

\author{
Mark C. Sullivan ${ }^{1, *}$, Robert K. Cowen ${ }^{1, *}$, Kenneth W. Able ${ }^{2}$, Michael P. Fahay ${ }^{3}$ \\ ${ }^{1}$ Marine Sciences Research Center, State University of New York at Stony Brook, Stony Brook, New York 11794-5000, USA \\ ${ }^{2}$ Marine Field Station, Institute of Marine and Coastal Sciences, Rutgers University, Tuckerton, New Jersey 08087, USA \\ ${ }^{3}$ National Marine Fisheries Service, Northeast Fisheries Science Center, Sandy Hook Laboratory, Highlands, \\ New Jersey 07732, USA
}

\begin{abstract}
With the recent decline of several exploited populations of northwest Atlantic fishes, effort has been directed toward understanding the scales at which recruitment varies along with the deterministic processes underlying this variability. Using surveys from 3 research submersible cruises $(1994,1997,1998)$, we examined the distributions of 4 species of recently settled groundfish in relation to spatial scale on the New York Bight region of the continental shelf (USA). A hierarchical sampling design was used to calculate the percent variability in abundance partitioned over 4 nested scales: submersible transect $(\sim 100 \mathrm{~m})$, site $(\sim 10 \mathrm{~km})$, shelf zone $(\sim 25 \mathrm{~km})$, and sampling line $(\sim 100 \mathrm{~km})$. For all years, early juveniles of Limanda ferruginea (yellowtail flounder) were highly concentrated at the shelf-zone scale, where abundance followed the thermal contours of a mid-shelf cold pool of remnant winter water. Conversely, Hippoglossina oblonga (fourspot flounder) and $\mathrm{Ci}$ tharichthys arctifrons (Gulf Stream flounder) were highly site-dependent, bounding the distribution of L. ferruginea at inner and outer shelf sites, respectively. Merluccius bilinearis (silver hake) exhibited moderate to high variability partitioned over several scales. For all species, the absence of sampling-line variability suggested that settlement patterns were consistent across the breadth of the shelf, while substantial residual variance suggested that microscale-level processes generated additional variability. Annual settlement of these early juveniles is highly specialized and cued to distinct aspects of the physical and biological setting of the New York Bight. Conceptually, these local habitat parameters can be used to link nodes of high variability with the possible deterministic processes modifying recruitment. Our results underscore the critical contribution juvenile nursery habitats may have to the subsequent survival and growth of continental shelf species.
\end{abstract}

KEY WORDS: Recruitment - Scale - Essential fish habitat - Continental shelf - New York Bight · Limanda ferruginea $\cdot$ Citharichthys arctifrons $\cdot$ Hippoglossina oblonga $\cdot$ Merluccius bilinearis

Resale or republication not permitted without written consent of the publisher

\section{INTRODUCTION}

Defining the mechanisms that generate variability in species abundance involves linking the scales at which variation is measured to the spectrum of scales over which deterministic processes operate (Huston 1999).

*Present address: Division of Marine Biology and Fisheries, Rosenstiel School of Marine and Atmospheric Science, University of Miami, Miami, Florida 33149-1098, USA. E-mail: msullivan@rsmas.miami.edu
In theory, the geographical range of a species consists of a network of occupied and unoccupied patches (Ricklefs 1990, Rotenberry \& Wiens 1998). Whether a given patch is occupied or not generally depends on the relative quality of the patch. Compounding this initial framework is the fact that patches often coexist within a complex hierarchy of multiple spatial and temporal scales (Kotliar \& Wiens 1990, Chesson 1997). Consequently, individuals respond to this hierarchy in diverse ways which are rarely manifested on a single, discrete scale. Unfortunately, many ecological investi- 
gations lack a priori knowledge of the range of scales over which this variability is most pronounced as well as the suite of deterministic processes which come into play (Levin 1992, Sale 1999).

Marine fish populations offer a unique challenge to the investigator interested in spatial scaling and the distribution of organisms. Fishes occupy an environment that is often difficult to define and have evolved corresponding life histories involving magnitude-order scaling differences between the larval and adult stages (Rothschild 1986). Benthic fishes are particularly problematic in this respect, as many species alternate between a 3-dimensional pelagic larval stage and a 2-dimensional benthic juvenile/adult stage. Early work on fish population structure sought to link population fluctuations with the size and corresponding dynamics of the adult spawning stock (Ricker 1954, Beverton \& Holt 1957). However, factors affecting the survival of early life stages, particularly the juvenile stage, profoundly influence subsequent year-class strength (Houde 1987, Post \& Evans 1989, Sogard 1992, Myers \& Cadigan 1993, Hixon \& Carr 1997, Able \& Fahay 1998). In temperate systems, fluctuations in abundance of juvenile fishes are invariably 'best explained' by scales corresponding with temperature and depth gradients (Colvocorresses \& Musick 1984, Gibson 1994, Neill et al. 1994). There is little doubt that temperature and depth exert a pervasive influence on all aspects of marine life histories. However, if these factors are the sole modifiers of recruitment variability (in this context, the transition from the pelagic larval stage to the benthic juvenile stage), it should be easy to predict year-class strength. This is not the case (Sissenwine 1984).

Observations of variability in recruitment have been exhaustively documented in the literature, and mechanisms proposed to explain where recruits are found and why: large-scale oceanography (Cowen 1985), warm-core rings (Myers \& Drinkwater 1987, Hare \& Cowen 1991), wind stress (Frank \& Leggett 1982, Peterman \& Bradford 1987, Thorrold et al. 1994), sediment type (Lough et al. 1989, Norcross et al. 1997), food availability (Lasker 1978, Sinclair \& Tremblay 1984), behavior (Leis et al. 1996, Stobutzki \& Bellwood 1998), reef structure (Ebeling \& Laur 1985, Carr 1989, Levin 1991), even sunspot activity (although for the invertebrate Cancer magister; Love \& Westphal 1981). A common thread running through a majority of studies is that results are often a direct function of the spatial/temporal scale investigated. A correlation with a habitat feature does not necessarily reflect the statistical aggregation of individuals to that feature nor does it imply that selective forces engineered the response (Rotenberry \& Wiens 1998). Walsh (1992) demonstrated that late-stage larvae of Limanda ferruginea are delivered to nursery areas on the Scotian Shelf via meso-scale circulation patterns (100s of kilometers) while actual settlement is cued to sediment grain size (10s of kilometers). To state that 'sediment type' alone determined the observed pattern (i.e. high abundance on sand) would be an oversimplification of a complex interaction. Recruitment is more realistically generated by a wave of deterministic processes acting in concert over several spatial and temporal scales (Neill et al. 1994). However, in the great majority of studies, variability is largely a function of unrecognizable (stochastic) or unsampled patchiness.

The New York Bight (NYB) encompasses a stretch of coastal ocean from Cape May, New Jersey to Montauk Point, New York (Long Island). The waters of the Bight have historically provided a valuable nursery habitat for commercially important benthic/demersal fish species, including Centropristis striata, Limanda ferruginea, and Merluccius bilinearis (McHugh 1972). Monthly beam trawl surveys (June 1996 to July 1997) have revealed strong, broad-scale habitat associations (10s of kilometers) for juveniles of several species, and provided an overview of community structure in general (Steves \& Cowen 2000, Steves et al. 2000). Recent submersible studies $(1994,1997,1998)$ have begun documenting smaller-scale microhabitat associations (0.01 to $0.1 \mathrm{~km}$ ) as well as the dispersion patterns of recent settlers (Sullivan et al. unpubl. data). Although a wide range of patch sizes (0.01 to 100 s of kilometers) corresponds with variations in juvenile abundance, no attempt has been made to link the scales at which recruitment is measured to the scales at which variability generating processes operate.

This study uses a hierarchical sampling program to: (1) identify the spatial scales over which abundances of 4 species of recently settled benthic fishes are most variable on the NYB continental shelf; (2) calculate the relative amount of variability encompassed at these respective scales; (3) develop an appropriate mechanistic framework for evaluating the processes responsible for generating local recruitment variability.

\section{METHODS}

Sampling design and technique. Hierarchical ANOVA techniques (e.g. nested ANOVA) have classically been used by quantitative geneticists who wish to gauge the magnitude of variance contributed by different levels of an experiment (Weir 1990, Sokal \& Rohlf 1995). Recently, investigators interested in the importance of scaling in population ecology have used this method to detect variability in abundance at multiple spatial scales (Morrisey et al. 1992, Lindegarth et al. 1995, Hughes et al. 1999). The hierarchical design of the present study was built around a video census of juvenile 
fishes from 3 late-summer (August 3 to 12, 1994; September 4 to 10, 1997; August 18 to 24; 1998) submersible cruises (Delta Oceanographics, Channel Islands Harbor, California) encompassing a total of 124 transects. Sampling configurations varied between years, depending upon weather conditions and cruise goals; however, all years accommodated at least 2 completely sampled lines of 5 to 7 sites (Fig. 1).

Typically, 4 submersible transects were completed at each site. Individual transects lasted $20 \mathrm{~min}$ and covered an average bottom area of $75 \mathrm{~m}^{2}$. Transect headings were determined randomly by a shipboard scientist, while quartets of transects were separated by 5 min transit periods during which juveniles were not counted. Observers counted all individuals within a $0.6 \mathrm{~m}$ wide swath (referenced by 2 centrally located laser lights, $0.2 \mathrm{~m}$ apart). Transects were recorded with an external Hi-8 $\mathrm{mm}$ Sony video system mounted on the front of the submersible and accompanied by an

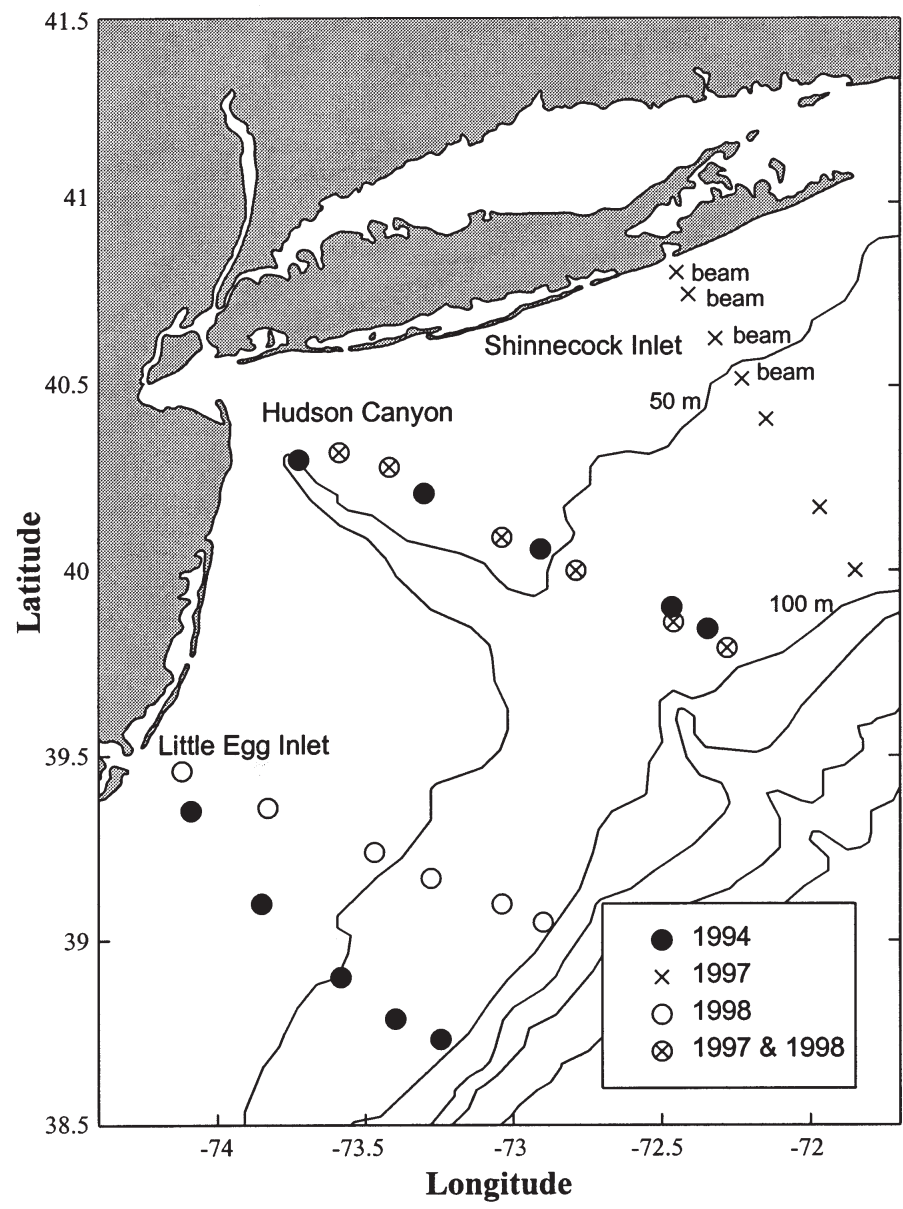

Fig. 1. Locations of underwater sites within New York Bight. First 4 sites of the upper transect (Shinnecock Inlet) were sampled with a $2 \mathrm{~m}$ beam trawl only in 1997. Identical sites were occupied on the central line (Hudson Canyon) in 1997 and 1998 audio 'narration' of species counts by the observer. Hydrographic data (conductivity, temperature, depth) was logged continuously with an external sensor array (Hydrolab Corp., Austin, Texas). Upon completion of a site, video tapes of individual transects were viewed a second time by the original observer and 2 additional scientists to verify counts within a given transect and resolve questionable identifications. This technique has proven to be extremely effective for deriving unbiased abundance estimates of highly cryptic benthic juveniles (Able et al. unpubl. data). Replicated $2 \mathrm{~m}$ beamtrawl tows were also performed at each site to further enhance species identification and size composition. In 1997, 4 of the 13 sites were sampled via beam trawl only due to inclement weather (Fig. 1). These abundances were converted to equivalent submersible counts with species-specific catchability coefficients derived from beam trawl/submersible efficiency comparisons. Species with consistently high numbers of young-ofthe-year juveniles among years were utilized in the hierarchical analysis: Limanda ferruginea (yellowtail flounder, sensu Cooper 1996), Hippoglossina oblonga (fourspot flounder), Citharichthys arctifrons (Gulf Stream flounder), and the merlucciid Merluccius bilinearis (silver hake). Information on settlement timing and agespecific distributions for these species can be found in Steves et al. (2000).

Statistical analysis. Hierarchical analysis of variance (ANOVA) techniques were used to partition the explained variability in abundance of each species by spatial scale (Underwood 1981, Searle et al. 1992). Sampling configurations were nested into the following hierarchy based purely on spatial considerations: sampling lines $(\sim 100 \mathrm{~km}$ each), shelf zones $(\sim 25 \mathrm{~km}$ each), sites $(\sim 10 \mathrm{~km}$ each), and submersible transects ( 100 m each) (Fig. 2). Accordingly, the linear model becomes,

$$
X_{i j k l}=\mu+L_{i}+Z(L)_{j(i)}+S[Z(L)]_{k[j(i)]}+\epsilon_{i j k l}
$$

where $\mu$ is the parametric mean of the population, $L_{i}$ is the contribution of the $i$ th subgroup (sampling line), $Z_{j(i)}$ is the contribution of the $j$ th subgroup (zone), $S_{k[j(i)]}$ is the contribution of the $k$ th subgroup (site) and $\epsilon_{i j k l}$ is the error term (replicate sub transect, residual). Thus, $X_{i j k l}$ is the observed abundance of Species $X$ on the lth submersible transect at the $k$ th site in the $j$ th zone of the $i$ th line. The magnitude of variation in abundance of settlers was evaluated among years using a singleclassification ANOVA design with 'year' as the only factor (Sokal \& Rohlf 1995). This hierarchical approach is particularly robust in that it allows spatial scales to be individually tested for significance while simultaneously deriving an estimate of the percent variance explained (Searle et al. 1992). However, it is important to note that our design is not completely balanced due to 


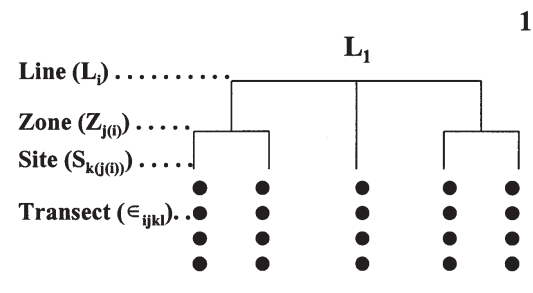

1994
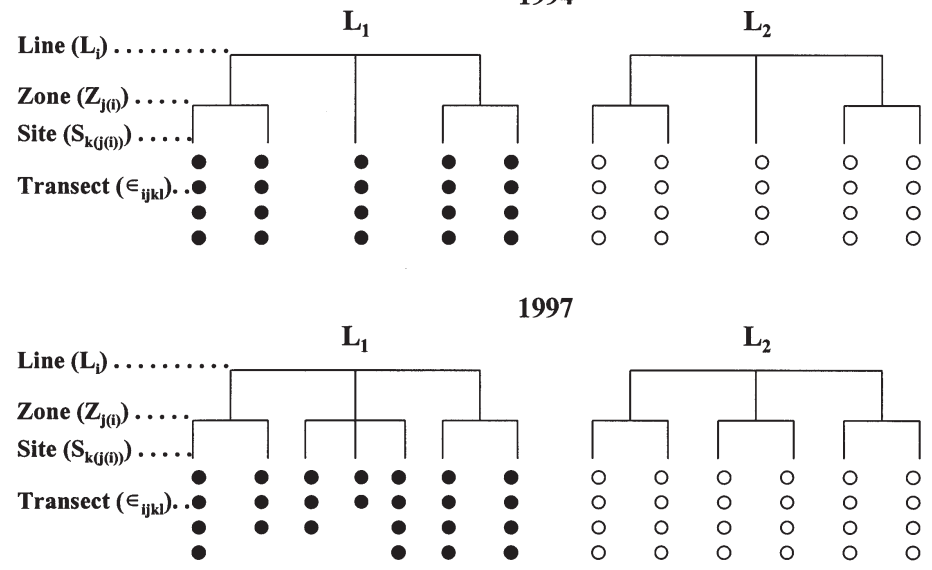

1997
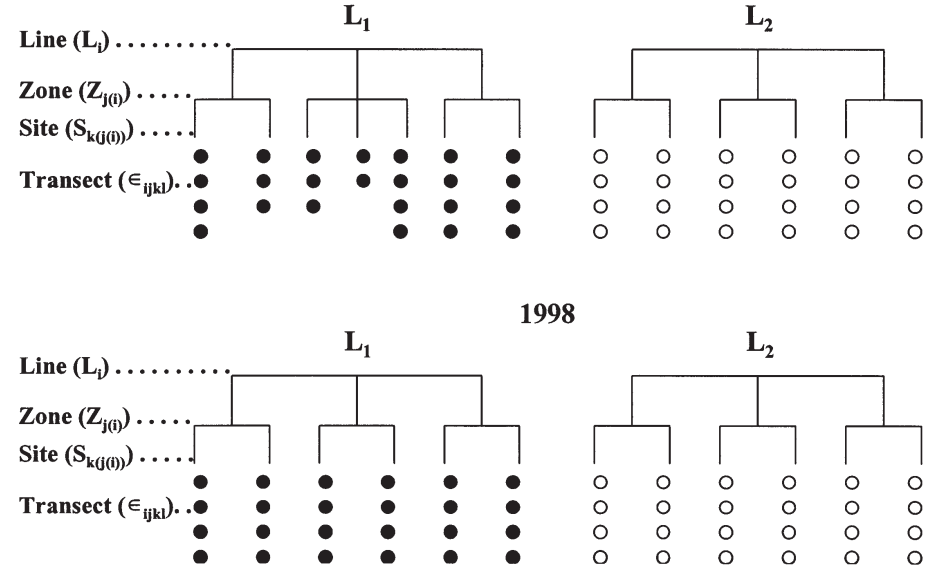

1998

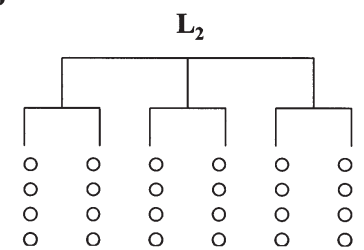

Fig. 2. Hierarchical groupings by year. Shaded and open circles differentiate separate lines $\left(L_{1}, L_{2}\right)$. Note some designs are not completely balanced due to sampling constraints.

(See second subsection of 'Methods' for definitions)

sampling constraints (most notably, adverse weather conditions in 1997). Underwood (1997), while acknowledging the significant drawbacks of an unbalanced design (alternative tests of significance such as the Satterthwaite approximation), recommends using all available data when faced with potentially low sample sizes. Rather than reducing submersible transects and dropping sites across the board, we opted to analyze a full complement of transects.

Nonparametric procedures. Variances of the abundance data were highly heteroscedastic at almost every spatial scale (Cochran's C-test; Fry 1993), with the exception of Limanda ferruginea in 1998. In some instances, $\log$ transformation, $\log (x+1)$, failed to homogenize variances. In order to confirm the validity of the parametric results, randomization tests were utilized to generate nonparametric distributions from randomly reordered variates (Manly 1991). Data matrices (species $\times$ year) were randomized and reanalyzed using hierarchical ANOVA ( $\mathrm{n}=5000$ iterations). The ANOVA test statistic ( $F$-value) obtained from the observed data was then compared against this randomized distribution of reordered values and a nonparametric significance level determined for each hierarchical level. The randomization test confirmed whether abundance varied significantly over a given scale.
Hierarchical ANOVA analyses were performed using BIOMstat (Version 3.2a, Applied Biostatistics, Inc., Setauket, New York). Cochran's C-test was calculated using Statgraphics (Version 3.0, Manugistics, Inc., Rockville, Maryland). Randomization tests were generated and evaluated with the MATLAB software package (Version 5.1, The MathWorks, Inc., Natick, Massachusetts).

\section{RESULTS}

\section{Settlement pattern and variability}

Over 3 sampling seasons (1994, 1997, 1998), more than 2000 recently settled benthic fishes were observed in the New York Bight on 124 different submersible transects (including 12 beam trawl tows), at 35 sites, in 18 zones, over 6 sampling lines. Settlement pattern was consistent among years for the 4 species examined (Fig. 3). Generally, individuals of Limanda ferruginea occupied combinations of mid-shelf sites, bounded by concentrations of Hippoglossina oblonga along the inner shelf, and Citharichthys arctifrons at the outer shelf. Merluccius bilinearis was less predictable from year-toyear, but typically settled over a range of mid/outer-shelf sites (Fig. 4). While recruitment pattern was predictable, recruitment magnitude was significantly different among years for individual species (Table 1). Furthermore, this variability was rarely tracked by all 4 species within a given year. For example, L. ferruginea and $H$. oblonga both peaked in 1994 (maximum individual transect abundance $=2.04$ and $0.52 \mathrm{~m}^{-2}$, respectively), while $C$. arctifrons and $M$. bilinearis peaked in 1997 (1.42 and $1.36 \mathrm{~m}^{-2}$, respectively; Fig. 3). However, all 4 species were characterized by average to poor settlement cohorts in 1998, with $H$. oblonga representing the absolute minimum over all years with only 9 recently settled individuals observed (Fig. 3). Because of this low sample size, $H$. oblonga was excluded from further statistical analyses for 1998.

Within years, patterns of abundance in relation to spatial scale were investigated using the hierarchical ANOVA design. Results are presented in terms of the significance of pattern as well as the relative magnitude of variation explained at each scale (Table 2, Fig. 5). Although various combinations of scales and species were shown to have no statistically significant added variance component, it is still appropriate to discuss the amount of variability contributed by these levels, as more degrees of freedom may be necessary to uncover a significant difference (Sokal \& Rohlf 1995). Variance components are partitioned as the percentages of the total variation in abundance explained for each year (i.e. the relative magnitude of variation). 

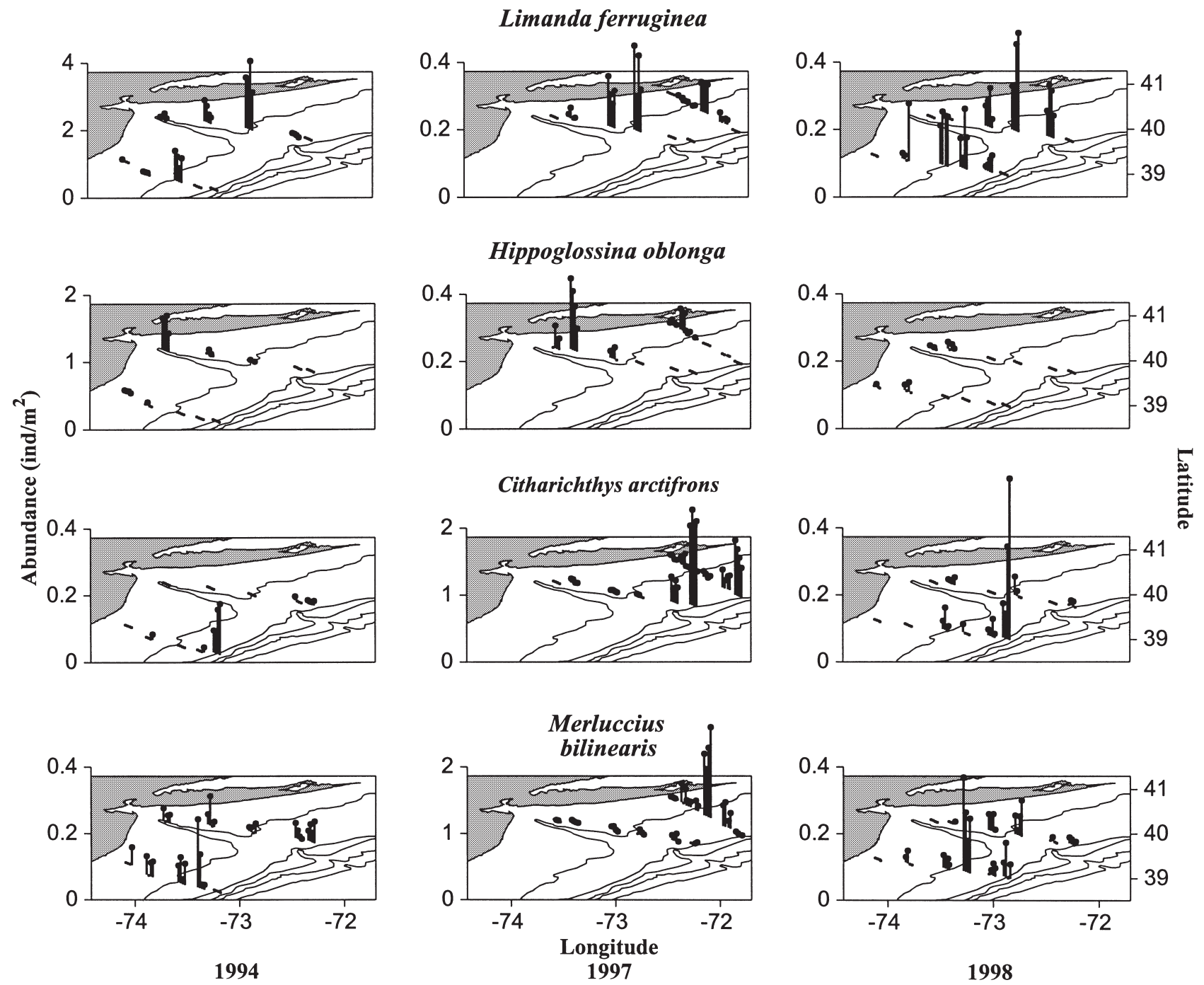

Fig. 3. Limanda ferruginea, Hippoglossina oblonga, Citharichthys arctifrons, and Merluccius bilinearis. Settlement pattern and variability in 1994, 1997 and 1998. Note varying scales of $z$-axis (abundance). The aspect ratio is skewed slightly to facilitate viewing of abundance magnitudes as well as the spatial orientation of sets of submersible transects

\section{Line}

For all 4 species, the sampling line level (100s of kilometers spatial scale) failed to contribute significantly to the observed variability in abundance during any of the 3 yr examined (Table 2). Merluccius bilinearis was moderately variable between-lines in 1997 $(28.1 \%$ variability explained); however, this component was not significant (Table 2). In order for line variability to be significant, constituent sites must differ consistently across entire sampling lines (for example, high abundance at 1 particular site cannot, in and of itself, generate substantial line variability). Consequently, several species exhibited minor percentages of line variation (Table 2) due to peaks at particular sites that did not propagate throughout entire lines:
1994, Hippoglossina oblonga (3.2\%), Citharichthys arctifrons $(3.0 \%) ; 1998, C$. arctifrons $(1.1 \%)$. None of these patterns was significant. In a statistical sense, the low number of degrees of freedom afforded by the line scale $(\mathrm{df}=1)$ made it the least powerful level in the hierarchy.

\section{Zone}

With 4 degrees of freedom throughout, the zone level was statistically more powerful than the line level, while arguably generating the most revealing patterns of any scale in the hierarchy. Limanda ferruginea had a statistically significant percentage of variability explained for multiple years at the zone level 

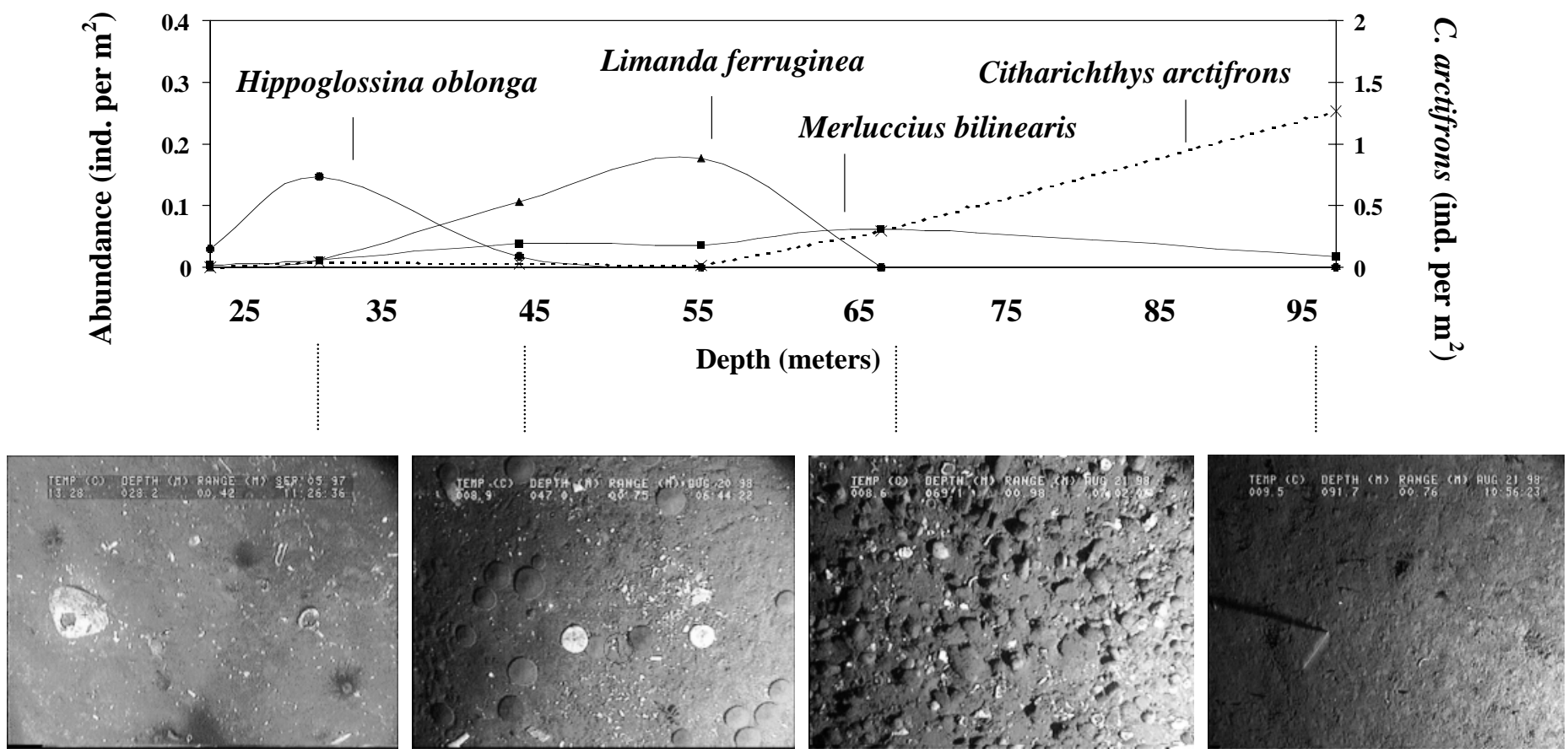

Fig. 4. Hippoglossina oblonga, Limanda ferruginea, Merluccius bilinearis and Citharichthys arctifrons. Cross-shelf early-juvenile distributions (individuals $\mathrm{m}^{-2}$ ) in relation to habitat. Note secondary $y$-axis for $C$. arctifrons. Data from central sampling line, 1997. Video shots show representative bottom types at selected depths

$(90.8 \%$ in $1994,68.9 \%$ in 1997 ; Table 2$)$. However, in 1998, patterns of abundance for L. ferruginea were only partially explained by this scale (37.5\%). Hippoglossina oblonga and Citharichthys arctifrons occasionally had substantial, but not significant, percentages of their total variability in abundance explained at the zone level (31.2 and $44.9 \%$, respectively in 1997 ; Table 2), while Merluccius bilinearis abundance was poorly explained at this scale during all years investigated ( $0 \%$ throughout).

\section{Site}

Although partitioned purely based on spatial considerations, the site scale (10s of kilometers) captured a wide range of variability. Consequently, this heterogeneity was reflected in the results. With the exception of Limanda ferruginea in 1994, all species exhibited highly significant $\mathrm{p}$-values at the site scale for all years (Table 2). Hippoglossina oblonga and Citharichthys arctifrons consistently had the highest percentages of variability explained at this level, with a maximum of 91.1 and $82.2 \%$, respectively. L. ferruginea and Merluccius bilinearis also exhibited consistent among-site variability; however, for the former, the bulk of the actual variance percentage was always concentrated at the zone level (with the exception of 1998).

\section{Transect}

The transect level (100s of meters) potentially offered the most rewarding results in terms of elucidating the role of microhabitat in generating variability. However, this level was also the most difficult to interpret. Being the lowest level in the hierarchy, the transect scale could not be tested statistically for significance (i.e. no lower mean square was available to generate an $F$ statistic; see 'Residual' in Table 2). Thus, the percentage of variation explained by this scale is a combination of transect level patchiness as well as unexplained, residual patchiness - presumably a function of lower, unsampled levels (see Chesson 1997). Generally, years of high abundance (Limanda ferruginea 1994, Hip-

Table 1. Limanda ferruginea, Hippoglossina oblonga, Citharichthys arctifrons, and Merluccius bilinearis. Results of singleclassification ANOVA testing among-year variability in abundance. Abundance data transformed $\log (x+1) .{ }^{* *} \mathrm{p}<0.01$

\begin{tabular}{|lcccrc|}
\hline Species & Source & df & MS & \multicolumn{1}{c|}{$F$} & $\mathrm{p}$ \\
\hline L. ferruginea & Year $^{* *}$ & 2 & 0.0580 & 10.57 & 0.0000 \\
H. oblonga & Year** $^{* *}$ & 2 & 0.0042 & 6.80 & 0.0015 \\
C. arctifrons & Year $^{* *}$ & 2 & 0.0659 & 15.54 & 0.0000 \\
M. bilinearis & Year $^{* *}$ & 2 & 0.0320 & 10.28 & 0.0000 \\
\hline
\end{tabular}


Table 2. Limanda ferruginea (Lf), Hippoglossina oblonga (Ho), Citharichthys arctifrons $(\mathrm{Ca})$, and Merluccius bilinearis $(\mathrm{Mb})$. Results of hierarchical ANOVA analyses testing effects of spatial scale on abundance. Randomization results are included to right of parametric values. ${ }^{*} \mathrm{p}<0.05,{ }^{* *} \mathrm{p}<0.01,{ }^{* * *} \mathrm{p}<0.001$

\begin{tabular}{|c|c|c|c|c|c|c|c|}
\hline Year, Source & $\mathrm{df}$ & Species & MS & $F$ & p-value & Random $\mathrm{p}$ & $\%$ explained \\
\hline \multicolumn{8}{|l|}{1994} \\
\hline \multirow[t]{4}{*}{ Line } & \multirow[t]{4}{*}{1} & $L f$ & 0.6799 & 0.35 & 0.589 & 0.508 & 0.0 \\
\hline & & Ho & 0.0715 & 1.19 & 0.337 & 0.322 & 3.2 \\
\hline & & $\mathrm{Ca}$ & 0.0041 & 1.20 & 0.335 & 0.330 & 3.0 \\
\hline & & $M b$ & 0.0011 & 1.32 & 0.315 & 0.320 & 1.7 \\
\hline \multirow[t]{4}{*}{ Zone } & \multirow[t]{4}{*}{4} & $L f$ & 1.9702 & 37.11 & 0.002 & 0.000 & $90.8^{* *}$ \\
\hline & & Ho & 0.0602 & 0.72 & 0.623 & 0.623 & 0.0 \\
\hline & & $\mathrm{Ca}$ & 0.0034 & 0.67 & 0.648 & 0.640 & 0.0 \\
\hline & & $M b$ & 0.0008 & 0.20 & 0.928 & 0.941 & 0.0 \\
\hline \multirow[t]{4}{*}{ Site } & \multirow[t]{4}{*}{4} & Lf & 0.0531 & 2.33 & 0.079 & 0.008 & 2.3 \\
\hline & & Ho & 0.0840 & 64.59 & 0.000 & 0.000 & $91.1^{* * *}$ \\
\hline & & $C a$ & 0.0051 & 23.26 & 0.000 & 0.000 & $82.2^{* * *}$ \\
\hline & & $M b$ & 0.0041 & 3.23 & 0.026 & 0.021 & $35.2^{*}$ \\
\hline \multirow{4}{*}{ Residual } & \multirow[t]{4}{*}{30} & $L f$ & 0.0228 & - & - & - & 6.9 \\
\hline & & Ho & 0.0013 & - & - & - & 5.7 \\
\hline & & $\mathrm{Ca}$ & 0.0002 & - & - & - & 14.8 \\
\hline & & $M b$ & 0.0013 & - & - & - & 63.1 \\
\hline \multicolumn{8}{|l|}{1997} \\
\hline \multirow[t]{4}{*}{ Line } & \multirow{4}{*}{1} & $L f$ & 0.0120 & 0.45 & 0.541 & 0.540 & 0.0 \\
\hline & & Ho & 0.0061 & 0.59 & 0.486 & 0.473 & 0.0 \\
\hline & & $\mathrm{Ca}$ & 0.1306 & 0.14 & 0.731 & 0.723 & 0.0 \\
\hline & & $M b$ & 1.0130 & 3.97 & 0.117 & 0.122 & 28.1 \\
\hline \multirow[t]{4}{*}{ Zone } & \multirow[t]{4}{*}{4} & Lf & 0.0269 & 8.21 & 0.009 & 0.013 & $68.9^{* *}$ \\
\hline & & Ho & 0.0142 & 2.30 & 0.159 & 0.144 & 31.2 \\
\hline & & $\mathrm{Ca}$ & 0.9613 & 2.92 & 0.103 & 0.103 & 44.9 \\
\hline & & $M b$ & 0.2545 & 1.03 & 0.456 & 0.439 & 0.0 \\
\hline \multirow[t]{4}{*}{ Site } & \multirow[t]{4}{*}{7} & $L f$ & 0.0033 & 5.67 & 0.000 & 0.001 & $17.6^{* * *}$ \\
\hline & & Ho & 0.0045 & 11.00 & 0.000 & 0.000 & $50.6^{* * *}$ \\
\hline & & $\mathrm{Ca}$ & 0.3290 & 73.81 & 0.000 & 0.000 & $52.5^{* * *}$ \\
\hline & & $M b$ & 0.2487 & 15.27 & 0.000 & 0.000 & $57.4^{* * *}$ \\
\hline \multirow[t]{4}{*}{ Residual } & \multirow[t]{4}{*}{35} & $L f$ & 0.0058 & - & - & - & 13.5 \\
\hline & & Ho & 0.0004 & - & - & - & 18.2 \\
\hline & & $\mathrm{Ca}$ & 0.0045 & - & - & - & 2.6 \\
\hline & & $M b$ & 0.0163 & - & - & - & 14.5 \\
\hline \multicolumn{8}{|l|}{$1998^{\mathrm{a}}$} \\
\hline \multirow[t]{3}{*}{ Line } & \multirow[t]{3}{*}{1} & $L f$ & 0.0013 & 0.04 & 0.849 & 0.853 & 0.0 \\
\hline & & $\mathrm{Ca}$ & 0.0216 & 1.09 & 0.356 & 0.397 & 1.1 \\
\hline & & $M b$ & 0.0099 & 0.99 & 0.376 & 0.367 & 0.0 \\
\hline Zone & 4 & $L f$ & 0.0323 & 2.74 & 0.130 & 0.130 & 37.5 \\
\hline & & $\mathrm{Ca}$ & 0.0199 & 1.34 & 0.357 & 0.204 & 9.3 \\
\hline & & $M b$ & 0.0100 & 1.00 & 0.475 & 0.450 & 0.0 \\
\hline Site & 6 & $L f$ & 0.0118 & 6.59 & 0.000 & 0.000 & $36.5^{* * *}$ \\
\hline & & $\mathrm{Ca}$ & 0.0149 & 4.79 & 0.001 & 0.000 & $43.6^{* *}$ \\
\hline & & $M b$ & 0.0100 & 11.67 & 0.000 & 0.000 & $72.7^{* * *}$ \\
\hline Residual & 36 & $L f$ & 0.0018 & - & - & - & 26.0 \\
\hline & & $\mathrm{Ca}$ & 0.0031 & - & - & - & 46.0 \\
\hline & & $M b$ & 0.0009 & - & - & - & 27.3 \\
\hline
\end{tabular}

counts within quartets of submersible transects (for example, 81, 74, 67, 81 individuals for $C$. arctifrons at the outer site of the central transect in 1997). Conversely, years with reduced abundances of settlers were characterized by higher percentages of among-transect variability (most notably C. arctifrons in 1998 with $46.0 \%$, and Merluccius bilinearis in 1994 with $63.1 \%$ ).

\section{DISCUSSION}

Tropical marine ecologists have confirmed the utility of investigating sources of variability at multiple spatial scales (Doherty 1991, Connell \& Kingsford 1998, Hughes et al. 1999). For example, Fowler et al. (1992) found recruitment pattern to be predictable among years at several scales (geographic, regional, site) for a coral reef fish, although recruitment magnitude was highly variable. Lindeman et al. (1998) recently used archived habitat data to develop a cross-shelf framework for synthesizing multiple scales of critical nursery habitat for juvenile snapper. To date, few temperate studies have addressed scaling issues on a multi-year, multi-species basis (but see Levin et al. 1997). The hierarchical approach taken by the present study facilitated the identification and characterization of spatial scales inherent in the recruitment success of 4 benthic fish species occupying settlement habitats on the NYB shelf (Fig. 5).

\section{Settlement pattern and variability}

Spatial information on settlement pattern and intensity is critical for poglossina oblonga 1994, Citharichthys arctifrons 1997) were characterized by negligible percentages of residual variance $(6.9,5.7,2.6 \%$, respectively), indicating that most of the observed variability was explained at higher hierarchical levels, in this case, site and zone. Indeed, juveniles often appeared to saturate a given underwater site, registering surprisingly consistent accurately characterizing where benthic species are found and why (Connell 1985). Cross-shelf patterns of settlement were similar among years (with the exception of Merluccius bilinearis), suggesting that juveniles require discrete nursery habitats which are utilized consistently from year to year (inner shelf: Hippoglossina oblonga, mid-shelf: Limanda ferruginea, outer 

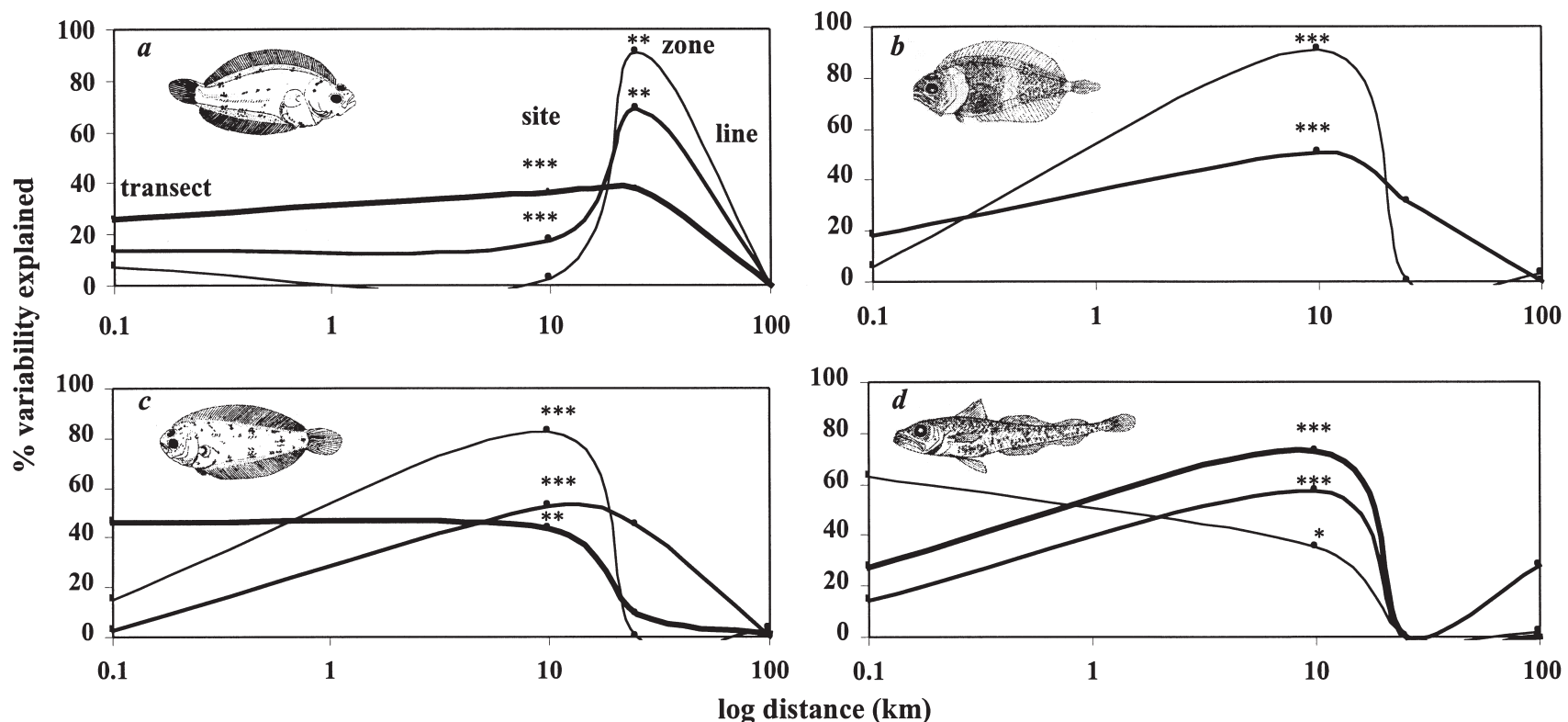

Fig. 5. (a) Limanda ferruginea, (b) Hippoglossina oblonga, (c) Citharichthys arctifrons, and (d) Merluccius bilinearis. Percent variability explained as a function of spatial scale. - 1994; - 1997; — 1998. Significant scales of variability are noted on each curve: ${ }^{*} \mathrm{p}<0.0{ }^{* *} \mathrm{p}<0.01{ }^{* * *} \mathrm{p}<0.001$

shelf: Citharichthys arctifrons: Fig. 4). These patterns agree with those reported by Steves et al. (2000) for the NYB shelf (beam-trawl assessment, 1996 to 1997). Similar juvenile zonation strata have been documented for other regional assemblages (Mid-Atlantic Bight estuary: Burke et al. 1991; Pacific Northwest inner continental shelf: Norcross et al. 1997; Gulf of Mexico estuary: Allen \& Baltz 1997), suggesting that early lifehistory strategies may evolve, in concert, to partition resources among species. On the NYB shelf (Steves et al. 2000), as well as within its estuaries (Able \& Fahay
1998), benthic fish distributions become less specialized and more cosmopolitan as the adult stage is approached, underscoring the critical contribution of these early stage benthic habitats to subsequent survival and growth.

In contrast to spatial pattern, the magnitude of settlement was extremely variable between years, and rarely tracked by all 4 species within a given year (Fig. 3). The potential causes and consequences of this variability, in conjunction with spatial scale, probably vary on a species to species basis.
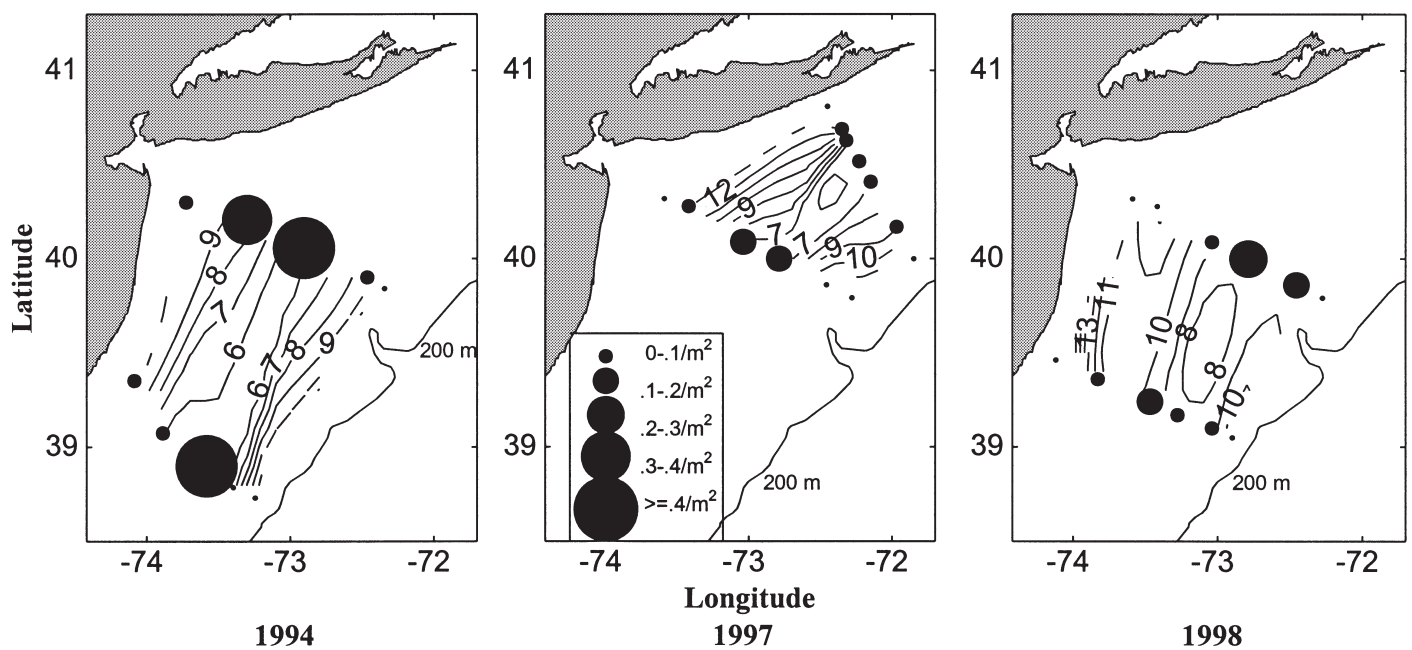

Fig. 6. Bottom temperature contours $\left({ }^{\circ} \mathrm{C}\right)$ and average abundance of Limanda ferruginea $(\bullet)$. Note single-station 'cold pool' shift (toward shelf break) in 1998 


\section{Limanda ferruginea}

A striking pattern among years was the fidelity of Limanda ferruginea to the zone scale $(=25 \mathrm{~km})$, where the dominant annual physical feature in the NYB (early summer to late fall) is a mid-shelf cold cell of remnant winter-bottom water (Houghton et al. 1982). This consistent spatial/temporal pattern is characterized by a pronounced accumulation of explained variability at scales of 25 to $50 \mathrm{~km}$ (Fig. 5a). Abundances of L. ferruginea in 1994 and 1997 were significantly related to the zone scale where 91 and $69 \%$ of the observed variability was explained, respectively (Fig. 5a). The highest concentrations of individuals for both years were located within the mid-shelf zone, where bottom temperatures reached a minimum of $6^{\circ} \mathrm{C}$ (with outer and inner-shelf zones ranging from 9 to $13^{\circ} \mathrm{C}_{;}$Fig. 6). This spatial pattern broke down in 1998, but only as a result of a single site extension of the cold pool into the outer-shelf zone (thus transferring a bulk of the variation to the site scale; Fig. 5a).

Ichthyoplankton work has revealed entire assemblages of larvae tracking water masses with distinct temperature and salinity signatures (Raynie \& Shaw 1994, Rakocinski et al. 1996, Grothues \& Cowen 1999). It is likely that late-stage larvae/early juveniles of Limanda ferruginea actively track the mid-shelf cold pool (or experience significant mortality outside its thermal boundaries), such that initial settlement patterns are set by processes operating at the zone level. Subsequent post-settlement mortality may, therefore, be more localized in nature (at particular sites or within individual transects), while directly contingent upon the longevity of the cell (Steves et al. 2000).

While the zone scale appears to be a critical node of recruitment variability for Limanda ferruginea, the lack of appreciable variance between sampling lines (100s of kilometers; Fig. 5a) suggests that settlement patterns are predictable across the breadth of the shelf. This is not a surprise, as juveniles of most NYB species (including the remaining 3 discussed herein) track discrete depth contours throughout settlement (Steves et al. 2000). Settlement intensity (i.e. the relative number of juveniles) was also consistent across the shelf within years (for example, the strong $L$. ferruginea settlement cohort of 1994: Fig. 3), indicating that fluctuations in shelf-wide larval supply may be synchronizing initial settlement magnitudes among sampling lines.

\section{Hippoglossina oblonga and Citharichthys arctifrons}

The distinctive settlement pattern of Limanda ferruginea is reinforced by the complementary distributions of the 2 other dominant shelf flatfish species,
Hippoglossina oblonga and Citharichthys arctifrons (Fig. 4). Both species exhibit inverse variability patterns to those displayed by $L$. ferruginea. High proportions of explained variability are partitioned into scales mirroring individual sites (10s of kilometers), with the zone scale playing a significantly reduced role (Fig. $5 \mathrm{~b}, \mathrm{c}$ ). Although both species track the inner and outer-shelf zones, respectively, suggesting a negative cold-pool relationship, the correspondence is not as predictable as with L. ferruginea (Fig. 3). For example, in 1997 a small tongue of $C$. arctifrons recruits extended into the innershelf zone of the northern line. Unfortunately, it is unclear whether this strong site attachment is a function of available pre-settlement individuals, post-settlement processes related to habitat, or an interaction of both (see Fowler et al. 1992 for the same dilemma). Although the variability curves are virtually identical for both species, $H$. oblonga and $C$. arctifrons settle into vastly different shelf habitats: the former into a high energy environment characterized by sand-wave ripples, scattered shell hash and cerianthid anemone fields, the latter into a barren, low-energy mud/silt landscape of polychaete mounds and marginated seastars (Sullivan et al. unpubl. data, Fig. 4 in present study). Experimental work has confirmed the importance of substrate type for growth and survival of numerous benthic fish species (Gibson \& Robb 1992, Neuman \& Able 1999); however, in nature, sediments often vary as function of temperature and depth, making correlations difficult to statistically resolve (Keefe \& Able 1994, Norcross et al. 1999, Steves et al. 2000).

Recent studies have suggested that pelagic, latestage larvae of some NYB species (Tautogolabrus adspersus, cunner, Etropus microstomus, smallmouth flounder; Cho 1996) as well as several South Atlantic Bight expatriates (Xyrichtys novacula, razorfish, Bothus sp.; Cowen et al. 1993) may use vertical migration behavior to mediate rapid cross-shelf transport from offshore sites to inshore nursery habitats. These observations implicate the influence of mechanisms operating on scales much greater than the final individual distributions would initially suggest. In this respect, caution should be used in attributing fluctuations in abundance among sites to processes operating strictly on comparable scales.

\section{Merluccius bilinearis}

In contrast to the complementary scaling patterns of the 3 flatfish, Merluccius bilinearis abundance was best explained by a broader band of moderate to high variability partitioned over a wide range of spatial scales $(0.1$ to $10 \mathrm{~km})$, with the site scale serving as the best proxy for settlement pattern (Fig. 5d). Steves \& 
Cowen (2000) suggest that early settlement patterns of $M$. bilinearis are cued to a narrow interaction of temperature and depth (indicative of spikes in abundance at single sites) with a subsequent broadening of habitat preference as juveniles grow and local physical regimes shift (turnover of the cold pool, mid-late fall). The zone scale was a poor indicator of abundance for this species (Fig. 5d) and, thus, may become more important only as individuals radiate out from particular sites.

\section{The importance of microhabitat}

One frequently undersampled scale of variation in temperate early life-history studies is the microhabitat level $(0.01$ to $0.1 \mathrm{~km})$, where variability is largely inaccessible by traditional sampling techniques (Felley \& Vecchione 1995). In the present study, submersible technology facilitated the accurate estimation of abundances of recent settlers, as well as their microscale habitat associations on the order of meters. In years where individuals saturated entire submersible transects (Limanda ferruginea in 1994, Citharichthys arctifrons in 1997), transect-level variability in abundance approached zero and the bulk of explained variability was contributed by sites and zones (Fig. 5a,c). This suggests a scenario whereby a species is swamping a given microenvironment with such intensity that microhabitat selection is virtually impossible. In contrast, during years of low overall abundance, species tended to exhibit high among-transect variability presumably a result of differential mortality or some form of habitat selection (C. arctifrons in 1998, Merluccius bilinearis in 1994; Fig. 5c,d). This scenario is con-

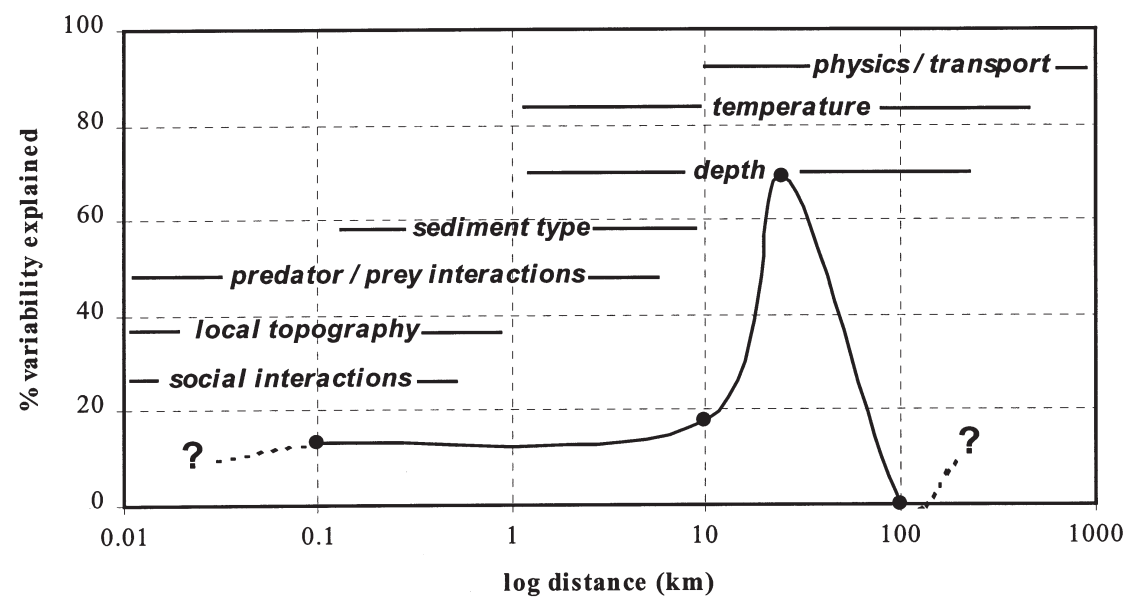

Fig. 7. Conceptual model of variability-generating mechanisms and their extents. Variance data taken from Limanda ferruginea 1997. Question marks depict scales not addressed in this analysis sistent with the habitat-suitability predictions of the basin model as proposed by MacCall (1990).

Recent submersible/remotely operated vehicle work in the Middle Atlantic Bight has suggested that juveniles, as well as adults, of many fish species select from the available background matrix, discrete microhabitat patches on the order of meters (Auster et al. 1995, 1997). Microhabitat structure is clearly critical for juvenile survival in some species. However, how this dependence filters up to population-level spatial scales is difficult to explain mechanistically. The tropical literature is replete with examples (both conceptual and empirical) of stage-specific habitat associations with population-level repercussions (Caley et al. 1996). Similar dynamics for temperate counterparts are just now beginning to be worked out for heavily exploited species such as Atlantic cod Gadus morhua (Lindholm et al. 1998). For example, on Georges Bank, late-stage cod larvae are delivered to potential nursery areas via mesoscale gyre circulation (100s of kilometers). Early juveniles then select for gravel substrates as a refuge from predation (100s of meters). Finally, late-stage juveniles abandon this gravel dependence and take up a more cosmopolitan existence (10 to $50 \mathrm{~km}$ scale) as adults (Lough et al. 1989, Langton et al. 1995, Langton 1998). Clearly, dynamics operating at lower scales cannot be completely ignored in the light of larger-scale physical processes.

A collection of recent studies has documented the impact of mobile fishing gear on a wide range of benthic habitats (Dayton et al. 1995, Auster et al. 1996, Currie \& Parry 1996, Kaiser \& Spencer 1996, Collie et al. 1997). Among these, Gislason (1994) estimates that the area swept annually by beam trawls in the North Sea is approximately equal to the entire area of the Sea itself. In order to completely gauge the importance of these lower scales of variability, experimental field studies must be performed to ascertain the short-as well as long-term impact of bottom disturbance on the survival of early-stage benthic fishes.

\section{Synthesis}

With the recent collapse of several significant northwest Atlantic fisheries, one of the critical concerns of fishery managers has been the identification and evaluation of 'essential fish habitat', EFH (Benaka 1999). For a majority of Northwest Atlantic species, critical knowledge has accumulated concerning the potential suites of habitats occupied by an 
Table 3. Limanda ferruginea. Selected studies addressing life-history aspects at various spatial scales. The smallest (0.01 km) and largest $(1000 \mathrm{~km})$ scales were not addressed in analysis of present study

\begin{tabular}{|llll}
\hline Scale $(\mathrm{km})$ & Region & Main objective & Source \\
\hline $0.01-1$ & NY Bight & Microhabitat associations & Sullivan et al. (unpubl. data) \\
$10-50$ & NY Bight & Juvenile nursery habitats & Steves et al. (2000) \\
& Review & Impact of habitat quality and quantity & $\begin{array}{l}\text { Gibson (1994) } \\
\text { Various }\end{array}$ \\
& Scotian Shelf & Density-dependent mortality & Cadigan (1993) \\
& Juvenile nursery habitats & Walsh (1992) \\
& Mid Atlantic Bight & Larval assemblages and hydrography & Grothues \& Cowen (1999) \\
& NY Bight & Larval assemblages and hydrography & Cowen et al. (1993) \\
& Scotian Shelf & Larval drift and distribution & Frank et al. (1992) \\
& Scotian Shelf & Larval drift and distribution & Walsh (1992) \\
& NW Atlantic & Latitudinal variability & Leggett \& Frank (1997) \\
& NW Atlantic & Latitudinal variability & Miller et al. (1991) \\
& Mid Atlantic Bight & Larval distributions & Morse et al. (1987) \\
& Mid Atlantic Bight & Community composition & Colvocoresses \& Musick (1984) \\
\hline
\end{tabular}

individual over its lifetime; however, in order to effectively manage exploited stocks, essential habitat must be considered explicitly in a spatial/temporal framework (Langton et al. 1995). This necessarily involves working from the population scale (where habitat scales are cumulative) downward. As demonstrated by the above discussion for the 4 NYB species and echoed by Levin (1992), attempting to dissect recruitment variability generating mechanisms into individual scales and processes is a difficult and, often, contradictory task. An alternative approach, as proposed by Langton et al. (1995), involves synthesizing pattern and process from a range of scales simultaneously.

A conceptual model for juveniles of Limanda ferruginea from the NYB illustrates the synergistic effect of multiple spatial scales (Fig. 7, Table 3). Areas of high variability (i.e. 25 to $50 \mathrm{~km}$ for $L$. ferruginea) can be used to create a framework within which one can gauge the relative importance of entire suites of scales. Thus, for L. ferruginea, complex evolutionary processes acting on population-level scales set the initial geographical range of the species (Miller et al. 1991). Scaling down into the New York Bight region, the sampling line scale reveals a settlement pattern for local populations that is predictable throughout the length of the shelf, and modified primarily by meso-scale processes (physics and transport). Among individual shelf zones (inner, mid, outer), juveniles are found predominantly within the confines of the mid-shelf cold pool, which exerts a profound influence on the basic physiology of individuals (via temperature and depth interactions). Within the cold pool itself, abundance is modified yet again as sediment type and its corresponding suite of prey and predator regimes come into play at individual sites. Among transects within sites, local microtopography (sand-wave fields, cover) as well as social interactions may modify distributions a final time, ultimately resulting in patterns which can be detected on the order of meters. In this example, while the distribution of scales spanned 4 orders of magnitude, the number of spatial scales directly addressed is probably an oversimplification (i.e. a large spatial gap exists between the 0.1 and $10 \mathrm{~km}$ levels). In addition, this framework will shift significantly with the vagaries of the geographical region under consideration (range location, habitat type, local physics) making the detection of pattern and process in this particular species more complex as one moves from region to region within its range (1000s of kilometers).

Despite providing valuable information regarding settlement pattern, variability and scaling, the present approach still amounts to what is essentially a series of static, single-stage snapshots (see Sale 1999 for a similar criticism). What is the relative abundance of competent pre-settlement larvae and how are they distributed? How have the observed juvenile abundances been modified by pre-sampling processes (i.e. Limanda ferruginea begins settlement as early as May)? In order to completely evaluate the interplay of multiple scales, future sampling clearly needs to be expanded in a spatial (concomitant larval sampling) as well as temporal (tracking of larval and juvenile abundances) sense. For the NYB, dynamics of larval and juvenile fish assemblages have been well-documented independently (Fahay 1983, Morse et al. 1987, Cowen et al. 1993, Steves et al. 2000); however, until attempts are made at synoptically linking both stages, a substantial piece of the recruitment mechanism remains unexplained. 
Acknowledgements. We gratefully acknowledge the patience and hard work of Dave Slater, Chris Ijames and Joe Lilly at Delta Oceanographics. The captain and crew of the RV 'Atlantic Surveyor' provided a more than capable platform for our dives, while Brian Hentschel and Waldo Wakefield offered logistical support. This fieldwork could not have been completed without the help of Jon Hare, Brian Steves, and Stacy Hagan. The manuscript itself benefited substantially from critical readings by Bob Cerrato, Mark Hixon, Su Sponaugle and 3 anonymous reviewers. Funding was generously provided by the National Underwater Research Program (NYB-94-17, MAB-97-3) and the American Museum of Natural History Lerner Gray Fund for Marine Research. This is Marine Sciences Research Center Contribution No. 1208 and Rutgers University Institute of Marine and Coastal Sciences Contribution No. 2000-19.

\section{LITERATURE CITED}

Able KW, Fahay MP (1998) The first year in the life of estuarine fishes in the Middle Atlantic Bight. Rutgers University Press, New Brunswick, NJ

Allen RL, Baltz DM (1997) Distribution and microhabitat use by flatfishes in a Louisiana estuary. Environ Biol Fish 50: 85-103

Auster PJ, Malatesta RJ, LaRosa SC (1995) Patterns of microhabitat utilization by mobile megafauna on the southern New England (USA) continental shelf and slope. Mar Ecol Prog Ser 127:77-85

Auster PJ, Malatesta RJ, Langton RW, Watling L, Valentine PC, Donaldson CLS, Langton EW, Shepard AN, Babb IG (1996) The impacts of mobile fishing gear on seafloor habitats in the Gulf of Maine (Northwest Atlantic): implications for conservation of fish populations. Rev Fish Sci 4:185-202

Auster PJ, Malatesta RJ, Donaldson CLS (1997) Distributional responses to small-scale habitat variability by early juvenile silver hake, Merluccius bilinearis. Environ Biol Fish 50:195-200

Benaka L (ed) (1999) Fish habitat: essential fish habitat and rehabilitation. American Fisheries Society, Bethesda, MD

Beverton RJH, Holt SJ (1957) On the dynamics of exploited fish populations. Fishery Invest, Lond (Ser 2) 19:1-533

Burke JS, Miller JM, Hoss DW (1991) Immigration and settlement pattern of Paralichthys dentatus and P. lethostigma in an estuarine nursery ground, North Carolina. Neth J Sea Res 27:393-405

Caley MJ, Carr MH, Hixon MA, Hughes TP, Jones GP, Menge BA (1996) Recruitment and the local dynamics of open marine populations. Annu Rev Ecol Syst 27:477-500

Carr MH (1989) Effects of macroalgal assemblages on the recruitment of temperate zone reef fishes. J Exp Mar Biol Ecol 126:59-76

Chesson PL (1997) Making sense of spatial models in ecology. In: Bascompte J, Sole RV (eds) Modeling spatiotemporal dynamics in ecology. Landes Bioscience, Austin, TX, p 151-166

Cho RD (1996) Vertical distributions of ichthyoplankton in the New York Bight with relation to potential cross-shelf transport and retention mechanisms. MS thesis. State University of New York, Stony Brook

Collie JS, Escanero GA, Valentine PC (1997) Effects of bottom fishing on the benthic megafauna of Georges Bank. Mar Ecol Prog Ser 155:159-172

Colvocoresses JA, Musick JA (1984) Species associations and community composition of Middle Atlantic Bight continental shelf demersal fish. Fish Bull US 82:295-313
Connell JH (1985) The consequence of variation in initial settlement vs. post-settlement mortality in rocky intertidal communities. J Exp Mar Biol Ecol 93:11-45

Connell SD, Kingsford MJ (1998) Spatial, temporal and habitat-related variation in the abundance of large predatory fish at One Tree Reef, Australia. Coral Reefs 17:49-57

Cooper JA (1996) Monophyly and intrarelationships of the family Pleuronectidae (Pleuronectiformes), with a revised classification. PhD thesis, University of Ottawa, Ottawa

Cowen RK (1985) Large scale pattern of recruitment by the labrid, Semicossyphus pulcher: causes and implications. J Mar Res 43:719-742

Cowen RK, Hare JA, Fahay MP (1993) Beyond hydrography: can physical processes explain larval fish assemblages within the Middle Atlantic Bight? Bull Mar Sci 53:567-587

Currie DR, Parry GD (1996) Effects of scallop dredging on a soft sediment community: a large-scale experimental study. Mar Ecol Prog Ser 134:131-150

Dayton PK, Thrush SF, Agardy MT, Hofman RT (1995) The impact of habitat disturbance by scallop dredging on marine benthic communities: what can be learned from the results of experiments? Aquat Conserv 5:205-232

Doherty PJ (1991) Spatial and temporal patterns in the recruitment of a coral reef fish. In: Sale PF (ed) The ecology of fishes on coral reefs. Academic Press, San Diego, p 261-292

Ebeling AW, Laur DR (1985) The influence of plant cover on surfperch abundance at an offshore temperate reef. Environ Biol Fish 12:169-179

Fahay MP (1983) Guide to the early stages of marine fishes occurring in the western North Atlantic Ocean, Cape Hatteras to the southern Scotian Shelf. J NW Atl Fish Fish Sci $4: 359$

Felley JD, Vecchione M (1995) Assessing habitat use by nekton on the continental slope using archived videotapes from submersibles. Fish Bull US 93:262-273

Fowler AJ, Doherty PJ, Williams D McB (1992) Multi-scale analysis of recruitment of a coral reef fish on the Great Barrier Reef. Mar Ecol Prog Ser 82:131-141

Frank KT, Leggett WC (1982) Coastal water mass replacement: its effect on zooplankton dynamics and the predator-prey complex associated with larval capelin (Mallotus villosus). Can J Fish Aquat Sci 39:991-1003

Frank KT, Loder JW, Carscadden JE, Leggett WC, Taggart CT (1992) Larval flatfish distributions and drift on the southern Grand Bank. Can J Fish Aquat Sci 49:467-483

Fry JC (1993) Biological data analysis: a practical approach. Oxford University Press, Oxford

Gibson RN (1994) Impact of habitat quality and quantity on the recruitment of juvenile flatfish. Neth J Sea Res 32: 191-206

Gibson RN, Robb L (1992) The relationship between body size, sediment grain size and burying ability of juvenile plaice, Pleuronectes platessa. J Fish Biol 40:771-778

Gislason H (1994) Ecosystem effects of fishing activities in the North Sea. Mar Pollut Bull 29:520-527

Grothues TM, Cowen RK (1999) Larval fish assemblages and water mass history in a major faunal transition zone. Contin Shelf Res 19:1171-1198

Hare JA, Cowen RK (1991) Expatriation of Xyrichtys novacula (Pisces: Labridae) larvae: evidence of rapid cross-slope exchange. J Mar Res 49:801-823

Hixon MA, Carr MH (1997) Synergistic predation, density dependence, and population regulation in marine fish. Science 277:946-949

Houde ED (1987) Fish early life dynamics and recruitment variability. Am Fish Soc Symp 2:17-29 
Houghton RW, Schlitz R, Beardsley RC, Butman B, Chamberlin JL (1982) The Middle Atlantic Bight cold pool: evolution of the temperature structure during the summer of 1979. J Phys Oceanogr 12:1019-1029

Hughes TP, Baird AH, Dinsdale A, Moltschaniwskyj NA, Pratchett MS, Tanner JE, Willis BL (1999) Patterns of recruitment and abundance of corals along the Great Barrier Reef. Nature 397:59-63

Huston MA (1999) Local processes and regional patterns: appropriate scales for understanding variation in the diversity of plants and animals. Oikos 86:393-401

Kaiser MJ, Spencer BE (1996) The effects of beam-trawl disturbance on infaunal communities in different habitats. J Anim Ecol 65:348-358

Keefe ML, Able KW (1994) Contributions of abiotic and biotic factors to settlement in summer flounder, Paralichthys dentatus. Copeia 2:458-465

Kotliar NB, Wiens JA (1990) Multiple scales of patchiness and patch structure: a hierarchical framework for the study of heterogeneity. Oikos 59:253-260

Langton RW (1998) Bottom habitat requirements of groundfish. In: Dorsey EM, Pederson J (eds) Effects of fishing gear on the sea floor of New England. Conservation Law Foundation, Boston, p 38-45

Langton RW, Auster PJ, Schneider DC (1995) A spatial and temporal perspective on research and management of groundfish in the northwest Atlantic. Rev Fish Sci 3: 201-229

Lasker R (1978) The relation between oceanographic conditions and larval anchovy food in the California Current: identification of factors contributing to recruitment failure. Rapp P-V Réun Cons Int Explor Mer 173:212-230

Leggett WC, Frank KT (1997) A comparative analysis of recruitment variability in North Atlantic flatfishes - testing the species range hypothesis. J Sea Res 37:281-299

Leis JM, Sweatman HP, Reader SE (1996) What the pelagic stages of coral reef fishes are doing out in the blue water: daytime field observations of larval behavioural capabilities. Aust J Mar Freshw Res 47:401-411

Levin PS (1991) Effects of microhabitat on recruitment variation in a Gulf of Maine reef fish. Mar Ecol Prog Ser 75: 183-189

Levin PS, Chiasson W, Green JM (1997) Geographic differences in recruitment and population structure of a temperate reef fish. Mar Ecol Prog Ser 161:23-35

Levin SA (1992) The problem of pattern and scale in ecology. Ecology 73:1943-1967

Lindegarth M, Andre C, Jonsson PR (1995) Analysis of the spatial variability in abundance and age structure of two infaunal bivalves, Cerastoderma edule and C. lamarcki, using hierarchical sampling programs. Mar Ecol Prog Ser 116:85-97

Lindeman KC, Diaz GA, Serafy JE, Ault JS (1998) A spatial framework for assessing cross-shelf habitat use among newly settled grunts and snappers. Proc Gulf Caribb Fish Inst 50:385-416

Lindholm J, Ruth M, Kaufman L, Auster P (1998) A modeling approach to the design of marine refugia for fishery management. In: Munro NWP, Willison JHM (eds) Linking protected areas with working landscapes, conserving biodiversity. Science and Management of Protected Areas Association, Wolfville, Nova Scotia, p 138-150

Lough RG, Valentine PC, Potter DC, Auditore PJ, Bolz GR, Neilson JP, Perry RI (1989) Ecology and distribution of juvenile cod and haddock in relation to sediment type and bottom currents on eastern Georges Bank. Mar Ecol Prog Ser 56:1-12
Love M, Westphal W (1981) A correlation between annual catches of Dungeness crab, Cancer magister, along the west coast of North America and mean annual sunspot number. Fish Bull US 79:794-796

MacCall AD (1990) Dynamic geography of marine fish populations. Washington Sea Grant Program, University of Washington Press, Seattle, Washington

Manly BF (1991) Randomization and Monte Carlo methods in biology. Chapman \& Hall, London

McHugh JL (1972) Marine fisheries of New York State. Fish Bull US 2:585-610

Miller JM, Burke JS, Fitzhugh GR (1991) Early life history patterns of Atlantic North American flatfish: likely (and unlikely) factors controlling recruitment. Neth J Sea Res 27:261-275

Morrisey DJ, Howitt L, Underwood AJ, Stark JS (1992) Spatial variation in soft-sediment benthos. Mar Ecol Prog Ser 81: 197-204

Morse WW, Fahay MP, Smith WG (1987) MARMAP surveys of the continental shelf from Cape Hatteras, North Carolina, to Cape Sable, Nova Scotia (1977-1984). Atlas No. 2. Annual distribution patterns of fish larvae. NOAA Natn Mar Fish Serv Tech Memo, US Dep Commerce-F/NEC-47: $1-215$

Myers RA, Cadigan NG (1993) Density-dependent juvenile mortality in marine demersal fish. Can J Fish Aquat Sci 50: 1576-1590

Myers RA, Drinkwater K (1987) The influence of warm core rings, the position of the shelf slope front, and the Gulf Stream on recruitment of fish from the Northwest Atlantic. J Mar Res 47:635-656

Neill WH, Miller JM, van der Veer HW, Winemiller KO (1994) Ecophysiology of marine fish recruitment: a conceptual framework for understanding interannual variability. Neth J Sea Res 32:135-152

Neuman MJ, Able KW (1999) Experimental evidence of settlement preference by early life history stages of windowpane (Scophthalmus aquosus). J Sea Res 40:33-41

Norcross BL, Mueter FJ, Holladay BA (1997) Habitat models for juvenile pleuronectids around Kodiak island. Fish Bull US 95:504-520

Norcross BL, Blanchard A, Holladay BA (1999) Comparison of models for defining nearshore flatfish nursery areas in Alaskan waters. Fish Oceanogr 8:50-67

Peterman RM, Bradford MJ (1987) Wind speed and mortality rate of a marine fish, the northern anchovy (Engraulis mordax). Science 235:354-356

Post JR, Evans DO (1989) Experimental evidence of sizedependent predation mortality in juvenile yellow perch. Can J Zool 67:521-523

Rakocinski CF, Lyczkowski-Shultz J, Richardson SL (1996) Ichthyoplankton assemblage structure in Mississippi Sound as revealed by canonical correspondence analysis. Estuar Coast Shelf Sci 43:237-257

Raynie RC, Shaw RF (1994) Ichthyoplankton abundance along a recruitment corridor from offshore spawning to estuarine nursery ground. Estuar Coast Shelf Sci 39:421-450

Ricker WE (1954) Stock and recruitment. J Fish Res Board Can 11:559-623

Ricklefs RE (1990) Ecology, 3rd edn. WH Freeman \& Co, New York

Rotenberry JT, Wiens JA (1998) Foraging patch selection by shrubsteppe sparrows. Ecology 79:1160-1173

Rothschild BJ (1986) Dynamics of marine fish populations. Harvard University Press, Cambridge, MA

Sale PF (1999) Recruitment in space and time. Nature 397: 26-27 
Searle SR, Casella G, McCulloch CE (1992) Variance components. Wiley Interscience, New York

Sinclair M, Tremblay MJ (1984) Timing and spawning of Atlantic herring (Clupea harengus) populations and the match-mismatch theory. Can J Fish Aquat Sci 41:1055-1065

Sissenwine MP (1984) Why do fish populations vary? In: May RM (ed) Exploitation of marine communities. SpringerVerlag, New York, p 59-95

Sogard SM (1992) Variability in growth rates of juvenile fishes in different estuarine habitats. Mar Ecol Prog Ser 85: $35-53$

Sokal RR, Rohlf FJ (1995) Biometry. The Principles and practice of statistics in biological research, 3rd edn. WH Freeman \& Co, New York

Steves BP, Cowen RK (2000) Settlement, growth, and movement of silver hake Merluccius bilinearis in nursery habitat on the New York Bight continental shelf. Mar Ecol Prog Ser 196:279-290

Steves BP, Cowen RK, Malchoff MH (2000) Settlement and nursery habitats for demersal fishes on the continental

Editorial responsibility: Kenneth Sherman (Contributing Editor), Narragansett, Rhode Island, USA shelf of the New York Bight. Fish Bull US 98:167-188

Stobutzki IC, Bellwood DR (1998) Nocturnal orientation to reefs by late pelagic stage coral reef fishes. Coral Reefs 17 : 103-110

Thorrold SR, Shenker JM, Maddox ED, Mojica R, Wishinski E (1994) Larval supply of shorefishes to nursery habitats around Lee Stocking Island, Bahamas. II. Lunar and oceanographic influences. Mar Biol 118:567-578

Underwood AJ (1981) Techniques of analysis of variance in experimental marine biology and ecology. Oceanogr Mar Biol Annu Rev 19:513-605

Underwood AJ (1997) Experiments in ecology: their logical design and interpretation using analysis of variance. Cambridge University Press, Cambridge

Walsh SJ (1992) Factors influencing distribution of juvenile yellowtail flounder, L. ferruginea, on the Grand Bank of Newfoundland. Neth J Sea Res 29:193-203

Weir BS (1990) Genetic data analysis: methods for discrete population genetic data. Sinauer Associates, Sunderland, MA

Submitted: January 15, 2000; Accepted: May 3, 2000 Proofs received from author(s): November 1, 2000 